\title{
A watershed approach to managing rainfed agriculture in the semiarid region of southern Mali: integrated research on water and land use
}

\author{
Birhanu Zemadim Birhanu ${ }^{1}$ D Kalifa Traoré2 ${ }^{2}$ Murali Krishna Gumma ${ }^{3}$. \\ Félix Badolo $^{1} \cdot$ Ramadjita Tabo $^{1} \cdot$ Anthony Michael Whitbread $^{3}$
}

Received: 27 September 2016 / Accepted: 29 March 2018 / Published online: 31 March 2018

(C) The Author(s) 2018

\begin{abstract}
Soil and water conservation (SWC) practices like that of erosion control and soil fertility measures were commonly practiced in the semiarid region of southern Mali since the 1980s. The SWC practices were mainly meant to increase water availability in the subsurface, reduce farm water runoff and gully formation and improve nutrient content of the soil, thereby increasing crop yield. Despite such efforts to promote at scale SWC practices, the landscape of southern Mali is still affected by high rates of runoff and soil erosion and low crop yield in farmers' fields. Data are lacking on previous beneficial SWC practices that could be adapted for wider application. In this paper, a watershed approach to managing rainfed agriculture is presented to show potential benefits of SWC practices at field and watershed scales. The approach included (1) community participation in establishing and monitoring new sets of hydro-meteorological monitoring stations and field experiments; (2) studying the dynamics and consumptive water uses of different land uses over time; and (3) evaluating the biophysical and economic advantages of SWC practices
\end{abstract}

Birhanu Zemadim Birhanu

z.birhanu@cgiar.org

Kalifa Traoré

ibosimon_1@yahoo.fr

Murali Krishna Gumma

m.gumma@cgiar.org

Félix Badolo

f.badolo@cgiar.org

Ramadjita Tabo

r.tabo@cgiar.org

Anthony Michael Whitbread

a.whitbread@cgiar.org

1 International Crops Research Institute for the Semi-Arid Tropics (ICRISAT), West and Central Africa (WCA), BP 320, Bamako, Mali

2 Laboratoire Sol- Eau- Plante Sotuba, Institut d'Economie Rurale (IER), BP 262, Bamako, Mali

3 ICRISAT, Patancheru, India 
implemented in the watershed. Results showed that over a period of 34 years (1980-2014) cropping area and consumptive water uses of crops (sorghum and cotton) increased at the expenses of natural vegetation. However, the yield of these crops remained low, indicating that soil fertility management and soil moisture were insufficient. In such cases, implementation of more SWC practices can help provide the additional soil moisture required.

Keywords Rainfed agriculture - Consumptive water use - Soil and water conservation · Contour bunding $\cdot$ Watershed management $\cdot$ Southern Mali

\section{Introduction}

Most agronomic research supporting development lays emphasis on farm-level productivity issues with limited efforts to manage interactions among components and actors beyond the level of the farm (German et al. 2005). For the semiarid region of southern Mali, Falconnier et al. (2016) argue that despite the demonstrated impacts of practices such as integrated soil fertility management (ISFM) and crop diversification through cereal-legume rotations or intercropping, wider dissemination of these practices has received scant attention. Smallholder farming in sub-Saharan Africa exhibits wide variability in household resource endowment and in soil fertility (Giller et al. 2011) thereby experiencing varying lengths of rainy days from year to year (Traore et al. 2013, 2017). This has resulted in wide range of yields within the same agro-ecological zone or even within individual farms. The few instances of increased production of cereal staples (millet and sorghum) were mainly due to land expansion rather than an increase in yield per ha (Traoré et al. 2014). This calls for a new integrated systems approach to improve the current agricultural practices using broader units of analysis and intervention, such as landscape, catchment and watershed (Blackie and Robinson 2007; Peterson et al. 2016; McCormack et al. 2016).

Land and water resources are increasingly scarce and are extensively used for agricultural systems, both in rainfed and irrigated semiarid regions of the world (Garg et al. 2012; Kumar et al. 2016). Rainfed agricultural systems rely almost exclusively on 'green' water resources, i.e., stored soil moisture from precipitation (Lathuillière et al. 2016), while irrigated systems also rely on water delivery from streams, aquifers or from water storage structures (McCartney and Smakhtin 2010). Both rainfed and irrigated systems have, however, failed to deliver the required demand over time due to rainfall variability, extreme weather events and loss of important nutrients due to erosion (Birhanu and Tabo 2016; Zemadim et al. 2014; Traoré et al. 2013). Another concern is the impact of land management practices (such as deforestation, over-grazing, improper farming practices and lack of appropriate SWC practices) in watershed areas that affect sustainable supply of water resources and soil health for agricultural development (Blackie and Robinson 2007).

Activities on integrated water and land use management can be addressed through watershed programs; hence, agricultural growth and development in most semiarid regions require investments in watershed management (Joshi et al. 2008; Wani et al. 2008; Garg et al. 2011). Natural resource management at the watershed scale (groundwater recharge for example) produces multiple benefits such as increasing food production, improving livelihoods, protecting the environment, addressing gender and equity issues along with biodiversity concerns (Rockström and Barron 2007; Rockström et al. 2010; Wani et al. 2011; Sun et al. 2016). The focus of a watershed program is not on individual farm productivity; 
rather, it considers the landscape and involves hydrological processes and the monitoring of land use practices (Swallow et al. 2001; Berg et al. 2016).

According to the US Environmental Protection Agency (US EPA), a watershed is defined as the area that drains into a common outlet (EPA 2012). A number of watershed programs (Blackie and Robinson 2007; Gomani et al. 2010; Kongo et al. 2010; Duvert et al. 2011; Zemadim et al. 2013; Bayabil et al. 2016) have been implemented since the 1980 s with the major objective of alleviating poverty and introducing sustainable development. Among the many watershed activities, SWC measures produce multiple benefits for livelihood security and environmental sustainability in most semiarid regions. Previous research in southern Mali also confirms this. The work of Traoré et al. (2004) and Doraiswamy et al. (2007) highlighted that SWC practices like that of erosion control and soil fertility measures were practiced in southern Mali since 1980s to increase water availability in the subsurface, reduce farm water runoff and gully formation and improve the nutrient content of the soil, thereby increasing crop yield.

In southern Mali, a total of 2562 cotton producing villages benefitted from SWC practices and other agricultural innovations through the Compagnie Malienne Pour le Développement des Textiles (CMDT) program. From 1982 to 2000, apart from SWC practices, CMDT provided support for the cash crop systems of cotton maize to utilize animal tractions and mineral fertilizer. In the early 2000s, CMDT reduced support for extension, literacy and road maintenance and was unable in some cases to provide agricultural inputs (seeds and fertilizer) or make payments for the cotton produce (Ollenburger et al. 2016). Individual farmers took the initiative to implement SWC practices in their fields after the support from CMDT discontinued (Bodnar 2005). Despite this information, data on the magnitude of implemented SWC practices and the potential benefits for wider dissemination are lacking. In addition, historical data on hydrology and crop yield pertaining to implementation of SWC practices are not available. Studies on the social acceptability of the practices through cost-benefit analysis are also lacking. The present study was aimed at providing useful information to understand whether adequate SWC practices were implemented to increase crop yield and the feasibility of expanding agricultural fields at the expense of natural vegetation. Therefore, the following activities were conducted in a small-scale watershed in southern Mali:

1. Use of a participatory watershed management approach to identify the current challenges of agricultural productivity and capture views from stakeholders on the existing land and water management practices;

2. Evaluation of the historical changes in land use, and the changes in consumptive water use for major crops and other land uses in the watershed; and

3. Evaluation of the biophysical and economic benefits of SWC practices through field experimentation.

\section{Materials and methods}

\subsection{Description of study site}

The study was conducted at Kani watershed, located in Kani village in southern Mali. The village is $450 \mathrm{~km}$ southeast from Bamako (Fig. 1) at latitude $12^{\circ} 15^{\prime} \mathrm{N}$ and longitude $5^{\circ} 10^{\prime} \mathrm{W}$ and at an altitude of $379 \mathrm{~m}$ above sea level. Space Radar Topographic Mission 


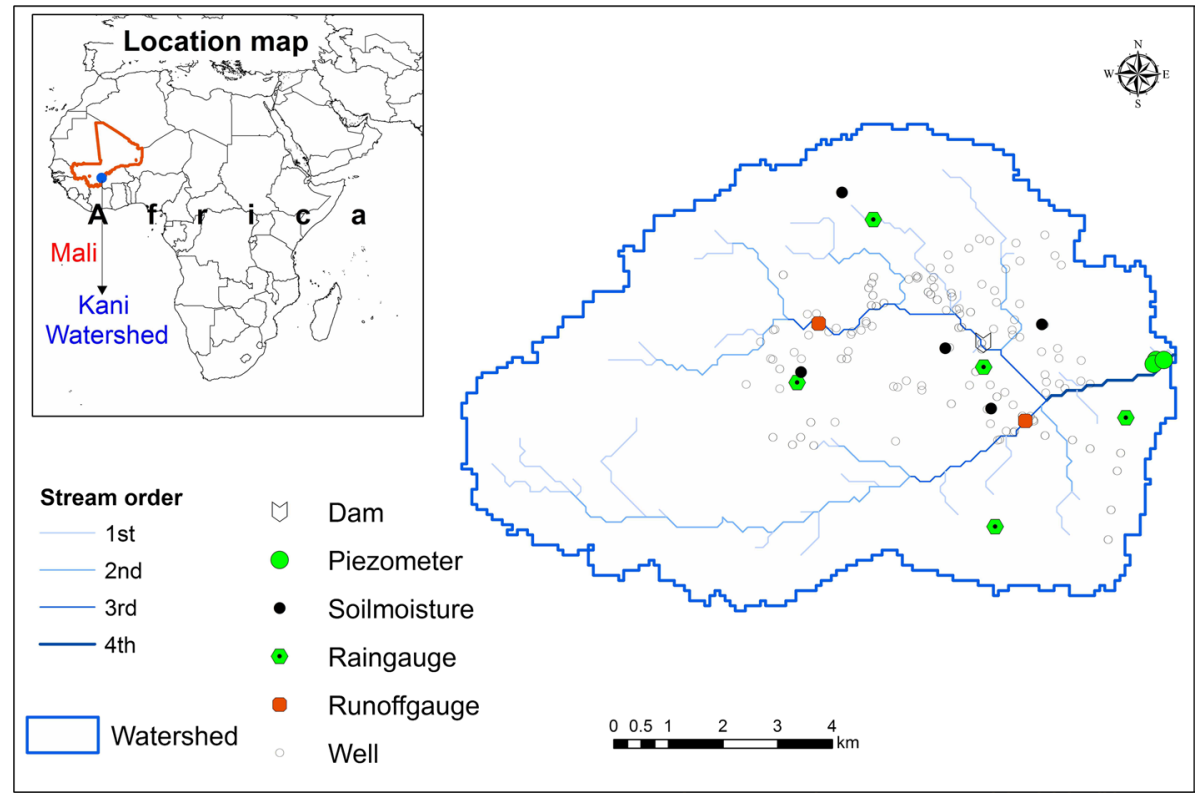

Fig. 1 Location of Kani watershed in southern Mali along with the newly established monitoring stations and community-managed shallow wells

(SRTM) data (Jarvis et al. 2008) were used to generate the hydrological boundary of the watershed. The watershed had a drainage area of 5780 ha with intermittent streams that sustain flow only for 2 months (November and December) after rainfall ceases in October. The village lies in the semiarid Sudanian zone with rainfall ranging from 800 to $1100 \mathrm{~mm}$ (Akinseye et al. 2016).

The mean number of annual rainy days computed from long-term (1980 to 2010) data, available from a weather station located in the district capital, Koutiala (latitude $12^{\circ} 23^{\prime} \mathrm{N}$, longitude $52^{\circ} 8^{\prime} \mathrm{W}$ and elevation $367 \mathrm{~m}$ ), was 75 . The maximum and minimum annual rainfall was $1358 \mathrm{~mm}$ (in 1994) and $516 \mathrm{~mm}$ (in 1984), respectively. The average daily maximum and minimum temperatures in the area were 35 and $22{ }^{\circ} \mathrm{C}$, respectively. The computed mean annual rainfall and mean annual potential evapotranspiration (PET) were 845 and $1552 \mathrm{~mm}$, respectively. The annual rainfall is concentrated in short periods of the year (July to September), and with the PET higher than rainfall for over 9 months of the year (October-June). Such conditions create challenges to store surface water in the area (Birhanu and Tabo 2016). A small dam was constructed (Fig. 1) to harvest rainwater for livestock use in the watershed. The dam dries up after 2 months when the rains end. Physical observation during the field visit in the dry season revealed that all streams in the area were dry, and soil was typically sand and sandy loam with shallow depth.

Similarly, during rainfall events all gullies and natural ponds are filled only to cause flooding on the plains and farmers' fields; stream channels are degraded; and highly eroded and the topsoil is easily detached, transported and deposited further downstream. Local communities attributed the drying of rivers and loss of topsoil to the arid conditions, shallow soils and lack of adequate SWC practices.

Rainfed agriculture is the main livelihood in Kani village with the production system mainly focusing on cotton and sorghum. The agriculture sector is heavily threatened by 
erosion and lack of soil fertility, resulting in the absence of changes in the cropping system for long periods, according to local communities' perspective. As more land becomes unproductive, farmers tend to cultivate upland areas near the plateaus. A few interventions rock bunds, contour bunds and contour ridge tillage are practiced in the local community to counter the effects of erosion, and composting has been widely promoted and adopted to improve soil fertility, although the authors have observed that composting was applied to the flatter farmlands without proper protection. In southern Mali reports by Traoré et al. (2017) and Van der Pol (1991) indicated that uneven rainfall distribution and heavy rain within very short periods of time led to a $40 \%$ water loss by runoff, which in turn, caused soil nutrient losses by an amount of $25 \mathrm{~kg}$ of $\mathrm{N} \mathrm{ha}^{-1}$ year $^{-1}$ and $20 \mathrm{~kg}$ of $\mathrm{K} \mathrm{ha}^{-1}$ year $^{-1}$.

\subsection{Participatory watershed management program}

For a watershed management program to be successful and sustainable, it is critical that problems and priorities be defined and diagnosed using participatory methodologies by the local actors themselves. Community involvement needs to be strongly supported by the scientific community to improve links between science and local planning policy (Zemadim et al. 2013). Further, a watershed management program should take into account the needs, constraints and practices of relevant users of the watershed and other stakeholders such as, policy makers, researchers and local NGOs. Users of the watershed include those who utilize watershed resources such as land, water, grazing area or trees with farmers considered as a subset of the watershed users. The participatory watershed development program in the present study had two steps: (1) stakeholder consultation program to identify the current challenges of agricultural productivity and to capture views from stakeholders on the existing useful land and water management practices; and, (2) establishment of hydro-meteorological monitoring stations with a participatory approach.

\subsubsection{Stakeholder consultation program}

Two stakeholder consultation workshops were conducted during the commencement of the watershed work in Kani village. The first workshop took place in April 2014 in the presence of village communities. The second district-level workshop in July 2014 was attended by a wide group of stakeholders, namely policy makers, district-level extension service providers, researchers, local NGOs and representatives from local communities. The stakeholder consultation program was generally guided by the mandatory issues of agricultural productivity and natural resources management set forth by German et al. (2005) and includes:

- Selecting a model learning site for research and capacity-building initiatives;

- Participatory research that includes local communities and their households;

- Sharing skills among researchers, extension officers, local NGOs and communities on improved practices of land and water management; and

- Understanding how interventions would change the livelihood conditions of local communities.

\subsubsection{Participatory approach to establish hydro-meteorological stations}

While there is an increasing number of published work on stakeholders' participation in environmental decision making, there are few concerning a participatory approach in 
Fig. 2 Establishing and monitoring biophysical information from Kani watershed: a rainfall measurement; b soil moisture measurement; c a locally trained observer taking soil moisture data; d shallow well monitoring; e established automatic weather station (AWS); f groundwater measurement from piezometers (tube wells); g setting up water runoff and erosion monitoring equipment. Photo credit: Birhanu Zemadim (2015)

quantitative environmental monitoring. A recent paper by Walker et al. (2016) stressed that in a region of low density and declining formal hydro-meteorological monitoring networks, a situation shared by much of the developing world community-based monitoring can fill the observational void by providing improved spatial and temporal characteristics of rainfall, river flow and groundwater levels.

In the Kani watershed, the installed monitoring stations consist of five rain gauges, an automatic weather station, ten soil moisture devices and three piezometers. Four water runoff and erosion monitoring stations were also established (Fig. 2a-g). The stations were installed from June 1 to 30, 2015. The rain gauges were manufactured locally after obtaining design standards from the Malian National Meteorological Agency (L'agence Nationale de la Météorologie). Campbell Scientific weather station was installed to monitor climatic variables such as rainfall, maximum and minimum air temperature, relative humidity, net radiation and corrected net radiation, solar radiation, wind speed and direction, soil temperatures at two depths $(10$ and $20 \mathrm{~cm})$ and barometric pressure at 1-h resolution.

The protocol for the design and installation of runoff and erosion monitoring equipment was obtained from the Institut d'Economie Rurale (IER). A runoff and erosion monitoring device was constructed locally. The equipment consists of (1) an oblique $40 \mathrm{~cm}$ long and $33 \mathrm{~cm}$ wide iron sheet, (2) a water supply pipe of $60 \mathrm{~cm}$ length, (3) two tanks of up to $200 \mathrm{~L}$ and (4) a cover sheet of $1.8 \mathrm{~m} \times 1.0 \mathrm{~m}$. These were placed in a pit $(1.5 \mathrm{~m} \times 0.7 \mathrm{~m} \times 1.3 \mathrm{~m})$ to capture runoff and erosion data from an area of $63 \mathrm{~m}^{2}$ (Fig. $2 \mathrm{~g}$ ).

The soil moisture was measured using Delta-T profile probes called PR2/6. These probes measure soil moisture at six depth layers $(10,20,30,40,60$ and 100$)$ below the ground surface. Plastic access tubes were installed in augured holes, and profile probes were inserted into these to take measurements (Fig. 2b, c). Dry condition soil moisture was recorded immediately after installation and before the commencement of rain. Local communities participated in setting up monitoring stations and were trained in data monitoring.

\subsection{Satellite imagery and analysis for land use and land cover mapping}

Blackie and Robinson (2007) believe that watershed studies are the only way to demonstrate the effects of a change in land use over an area, in a way that plot studies and mathematical models fail to do. The literature on land use and land cover changes (Gumma et al. 2016) reported that single-date fine-resolution imagery is sufficient to precisely identify where crops are growing and evaluate the changes over a period at a watershed scale. Given this background, this paper maps the land use changes in the study area to provide inputs toward decision making in a watershed. The images were available for the years 1986, 1991, 2002 and 2014 during the cropping season in the respective years. The images were selected systematically to show the ex-ante and ex-post situations of SWC practices in the watershed. The first two images, i.e., 1986 and 1991, showed the land use situation during the beginning years of SWC practices. The image from 2002 was selected to show the land use situation immediately after the intervention of SWC by CMDT was stopped. The 2014 image showed the recent situation of land use after over 30 years of SWC implementation in the watershed. 
A

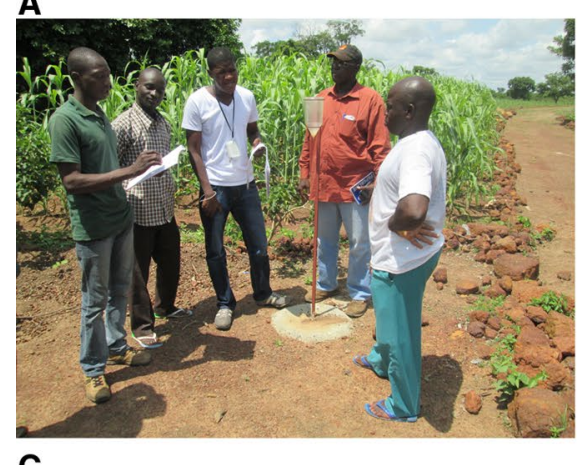

C

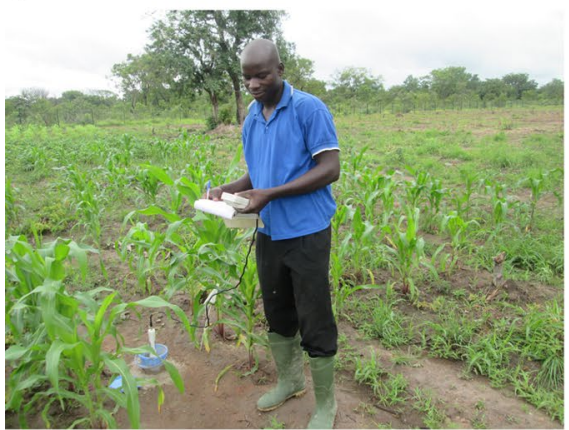

E

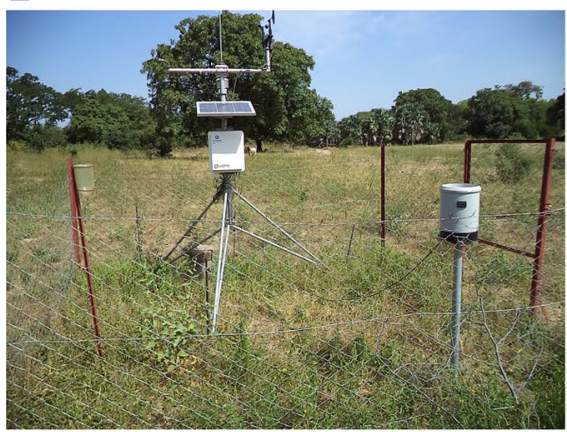

B

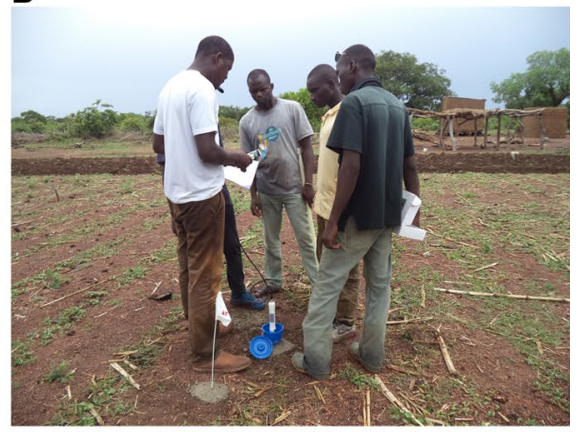

D

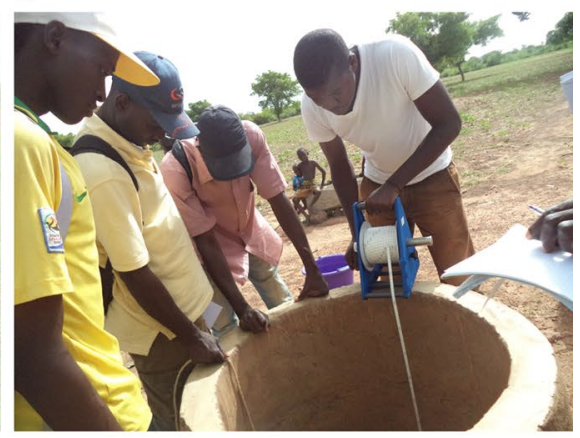

F

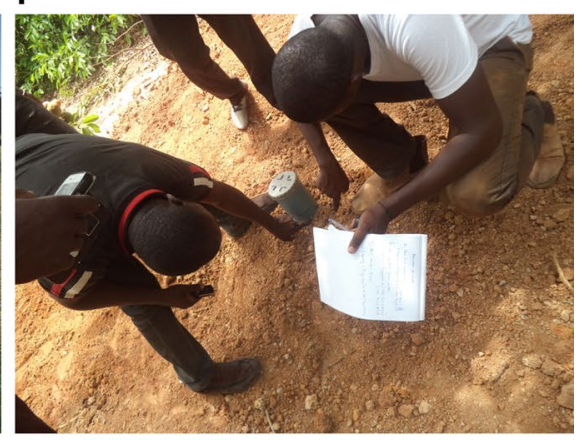

G

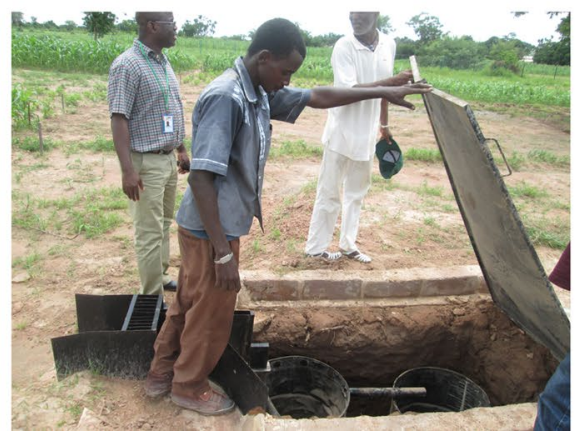


Since multi-year data are being analyzed, the images were converted into top of atmosphere (ToA) reflectance using a reflectance (Tucker et al. 2004) model built in ERDAS IMAGINE Modeler based on the equations and algorithms presented by Gumma et al. (2011). Each year, the data set was then classified using unsupervised ISOCLASS cluster K-means classification. The class identification and labeling process involved the use of various data sets such as bi-spectral plots, ground data, Google Earth high-resolution imagery as reference and MODIS time series signatures for each year (Gumma et al. 2011, 2012, 2016).

\subsection{Consumptive water use}

Consumptive water use (CWU) is the quantity of water used by the vegetation growth of a given area. It is the amount of water required by a crop for its vegetated growth to evapotranspiration and building of plant tissues plus evaporation from soils and intercepted precipitation. It is expressed in terms of depth of water. Consumptive use varies with temperature, humidity, wind speed, topography, sunlight hours, method of irrigation and moisture availability. For crop production, CWU refers to the total evaporative use of a crop during the crop growth period, often termed evapotranspiration (ET) (Liu et al. 2009).

Several methods exist to compute the CWU by crops and vegetation. The most widely used method in the semiarid regions at a small watershed scale is the computation of average monthly consumptive use using Blaney-Criddle method (Blaney and Criddle 1950). This method entails the use of mean air temperature, possible percentage of daytime hours of a year during each month and a use coefficient for each crop. In an effort to better describe a use coefficient on the basis of relative humidity in different geographies and climatic regions, McDaniels (1962) presented Eq. 1 to compute monthly and seasonal CWU:

$$
\text { Consumptive Water Use }(\mathrm{CWU})=25.4 \times \sum_{i}^{n} \text { Climatic Index }(\mathrm{CI})_{i} \times \operatorname{Use} \operatorname{Coefficient}(\mathrm{UC})_{i}
$$

where CWU(in $\mathrm{mm}$ ) is the average depth of water required for the growth and full development of a crop under conditions favorable to the production of agricultural crops having a full water supply; 25.4 refers to the conversion of inch to $\mathrm{mm}, \mathrm{CI}$ is a number expressing a composite relation of climatic factors during each month $i$, and $\mathrm{UC}$ is a factor representing physiological characteristics of a plant, together with the effect of atmospheric phenomena other than air temperature and the possible percentage of daytime hours of a year during each month $i$. $n$ refers the total number of growing months.

Liu et al. (2009) presented Eq. 2 to aggregate CWU at a watershed or grid scale from specific land uses.

$$
\mathrm{CWU}=\frac{\sum_{k=1}^{n}(\mathrm{CWU} k \times A k)}{(10)^{5}}
$$

where CWU is the total consumptive water use in million metric cube $\left(\mathrm{Mm}^{3}\right)$ per year, CWU $k$ and $A k$ are the consumptive water use (in $\mathrm{mm}$ per year) and area (in ha) for specific land use or land cover $k$, respectively, and $n$ is the total number of land uses in the watershed.

The CWU estimate in the present study was compared with estimate provided by the Food and Agricultural Organization (FAO) working manual (Critchley et al. 1991). 


\subsection{SWC experimental setup and biophysical monitoring}

The most common SWC practice implemented in southern Mali is the contour bunding technique (CBT). CBT is a well-known method for reducing water runoff and for controlling soil erosion. The application involves creation of permanent contour ridges covered with perennial grasses, whereby farmers follow the ridges to prepare the farm plot for crop production (Zemadim et al. 2014). Other potential benefits of CBT are improving crop yields and household food security (Gigou et al. 2006; Traoré et al. 2017).

Water runoff and erosion were monitored in two adjacent fields. Each field was divided into two parts and four sets of water runoff and erosion equipment were installed. In the first field, ridges followed the CBT, while in the second field, traditional farmer practices labeled as non-contour bunding (NCB) were considered as a control. Two replications were implemented in the CB field and two others in the NCB field. The treatment and control plots were homogeneously managed in terms of field operations and crop species. The first measurement began on June 26, 2015, and data were collected during each rainfall event, generating runoff for the years 2015 and 2016. At the end of the rainy season, runoff rates (R) were determined for each rainfall event using two equations (Eqs. 3 and 4):

$$
R=\frac{\text { Runoff water }(\mathrm{mm})}{\text { Rainfall received }(\mathrm{mm})}
$$

$$
\text { Runoff water }=\frac{\text { Volume of water generated }\left(\mathrm{m}^{3}\right)}{\text { Measurement area }\left(\mathrm{m}^{2}\right)}
$$

Soil moisture is a key state variable in a watershed that controls hydrological processes at various spatial scales (Berihun et al. 2016; Peterson et al. 2016). Identification of patterns of soil moisture response to rainfall and especially the vertical dynamics of soil moisture at hill slope or farm scale can be useful for investigation of runoff generation processes and in situ water conservation options (Blume et al. 2007). In this case, soil moisture monitoring stations were useful to evaluate the moisture storage dynamics in the subsurface condition. Average soil moisture data from the six layers were used to describe the soil moisture status of the watershed over time. Soil moisture data were analyzed against different rainfall events, and over different soil layers for two agronomic seasons (2015 and 2016) to understand plant water availability and the long-term consumptive use of water by field crops and other land uses in the watershed.

\subsection{Economic analysis of SWC practices}

Partial budget method was used for the cost-benefit analysis of agricultural field crops production with and without CBT. Partial budget analysis is a simple and effective technique for assessing the profitability of new technology on the farm. It provides the foundation for comparing the relative profitability of alternative treatments and shows the effect of changes in farm operations. For example, farmers know that application of CBT is likely to increase yields, and thus the gross income. The use of CBT also results in additional costs. To decide whether to use CBT for crop production or not requires a cost-benefit analysis through partial budget method. The method is applied on a sample of 138 farmers interviewed through a field survey conducted in 2016. Partial budget method goes through 
many steps. For the purposes of the present study, we focused on the following description and steps of analysis:

- Yield The quantity of output produced per unit area, usually expressed in $\mathrm{kg} / \mathrm{ha}$.

- Adjusted yield The experimental yield scaled down by a given proportion to approximate the yield that farmers can obtain on their farms. The scaling down is necessary to prevent overestimation of the returns that farmers are likely to obtain from a treatment. Experimental yields are higher than farmers' yield because of higher management level, smaller plot size, precision in harvesting date and better harvesting methods. The difference between yield from experimental field and farmer's field in similar cropping conditions will be the basis for the scaling down.

- Farm gate price of the output The value (price) that farmers receive or can receive for their harvested crops. By this definition, it is the price farmers receive at the end of the production process.

- Gross farm gate benefit The product of the farm gate price of the output and the adjusted yield.

- Total variable input cost The sum of all variable input costs, this varies from one treatment to another. These are farm gate costs of the variable inputs for each of the treatments.

- Net benefit The difference between the gross farm gate benefit and the total variable input cost.

- Marginal rate of return This is a ratio of the change in net benefit to change in total variable input costs between treatments.

Figure 3 presents the analytical framework of the methodology applied in the current study.

\section{Results and discussion}

\subsection{Stakeholder consultation program}

Four major constraints of agricultural productivity were identified during the stakeholder consultation program: (1) water scarcity (both surface and ground); (2) soil erosion associated with soil fertility; (3) health issues as a result of improper agricultural inputs; and (4) livestock issues related to lack of animal fodder and traction. Actions taken by the rural communities to avert these challenges over the past 30 years were discussed, along with the efficiency of each intervention measure (Table 1). The stakeholder consultation forum revealed that farmers are positively inclined toward the use of SWC practices mainly to improve crop yield. However, there are still some challenges and a lack of proper awareness that prevent wide implementation of SWC practices. Some of these are presented in Table 1. Further to the stakeholder consultation program, available publications showed the agricultural system in Mali is challenged by climate variability and other factors. Ebi et al. (2011) and Rahman (2006) showed occurrence of many hotter and drier days over the last several decades in Mali which in turn caused scalding in cereals, disturb flowering and strongly reduce crop yield. Butt et al. (2005) reported that the precipitation trend in the southern part of Mali during the years 1960 to 2005 showed significant reduction in rainfall in the wettest months (July and August), and an increase in precipitation at the 


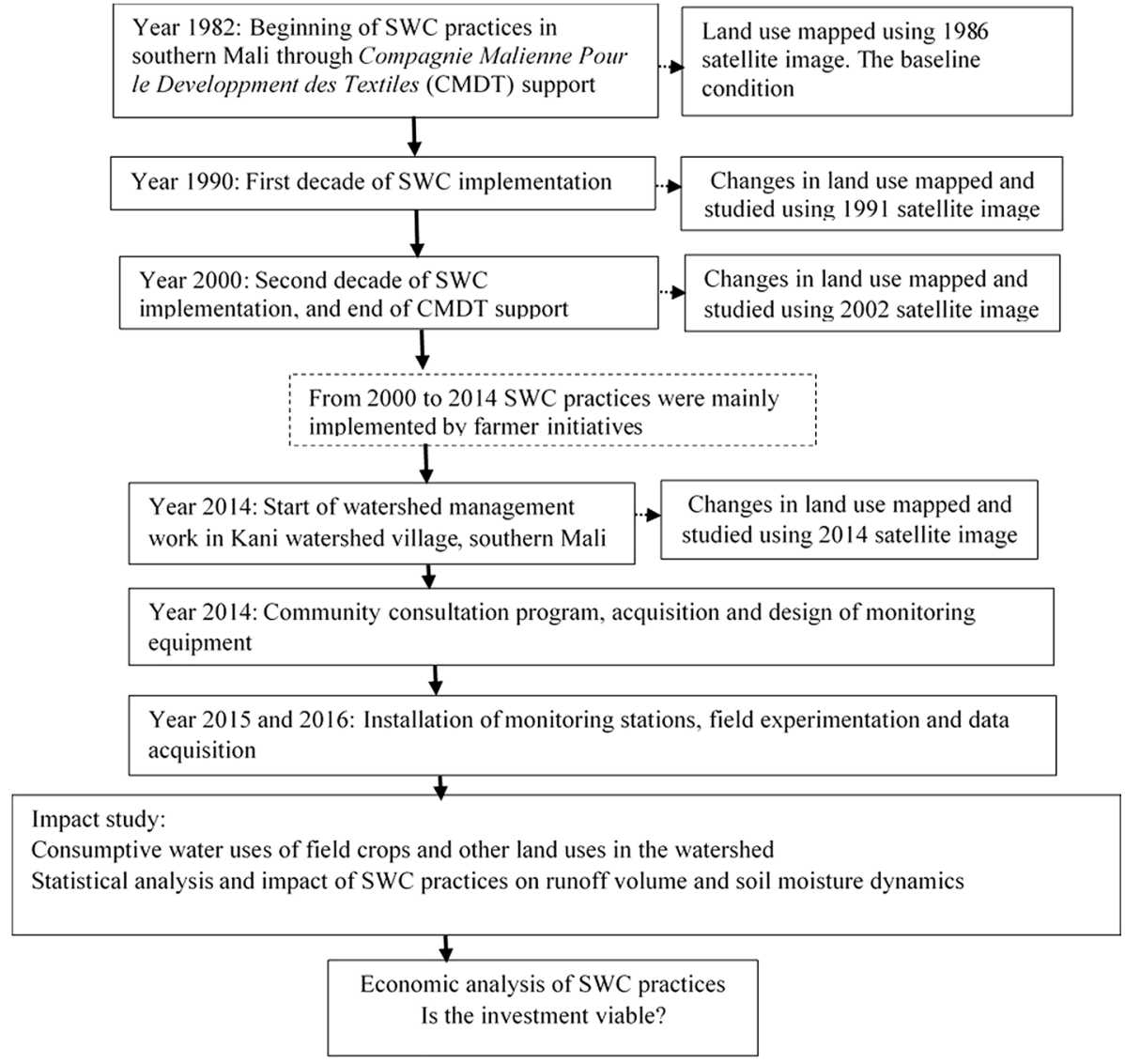

Fig. 3 Analytical framework describing watershed approach to study water and land use in Kani village, southern Mali

beginning of the rainy season. Other constraints to the agricultural system in the region are related to availability of labor, poor adoption rates of agricultural inputs, for example fertilizer rates and poor fertility of the soil. As a result of these agricultural productivity is in adequate to feed Mali's population and rural communities at large are unable to cope with the impacts of climate variability (Zemadim 2016).

\subsection{Historical changes in land use, and the consumptive water use}

Land use and land cover (LULC) completes the landscape in the watershed/village. Production practices, management practices and other socioeconomic factors define the sustainability of the agricultural system as well as stimulate changes based on other biotic and abiotic factors. The scale of the watershed and the factors operating at that scale are linked to a higher order of the same system; they in turn, influence the lower order systems. Similarly, LULC is one important production variable which changes along with influencing factors such as water availability, soil quality, seed, market access, etc. 


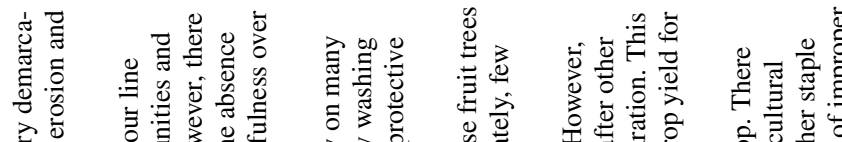

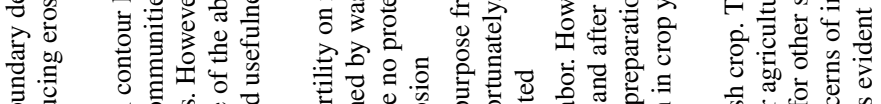

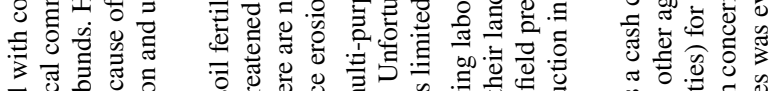

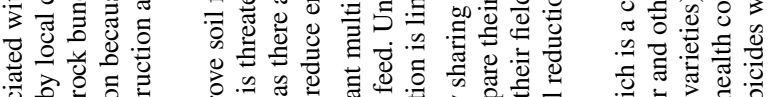

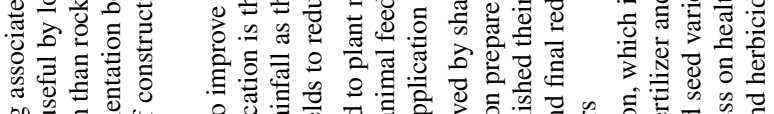
on

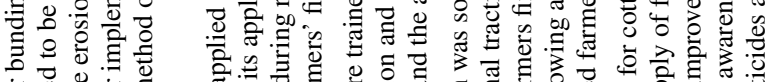

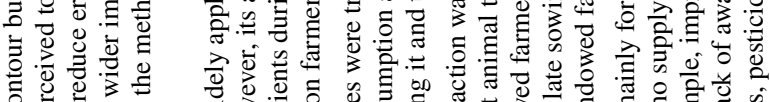

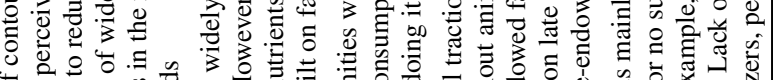

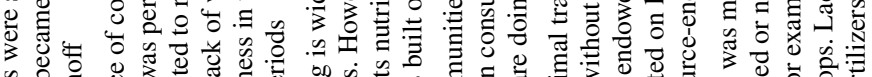

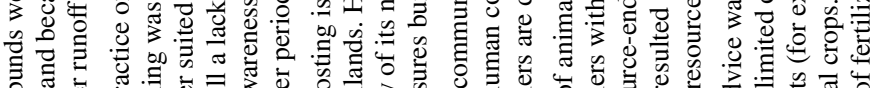

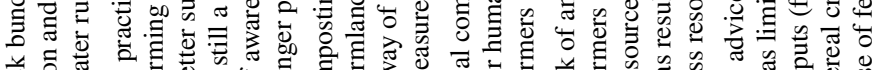

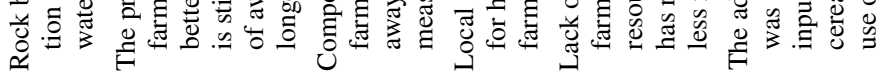
○

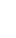
ज्ञ ¿ृ

$\frac{5}{2}$

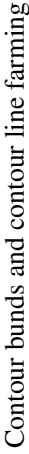

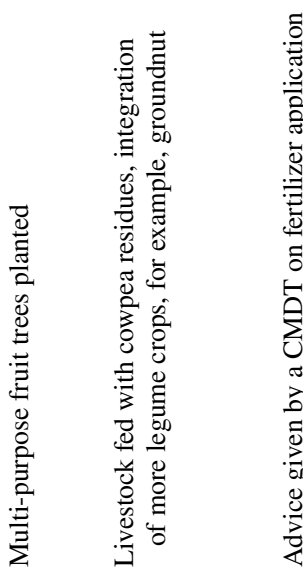

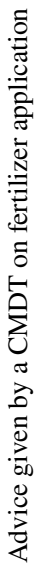

产

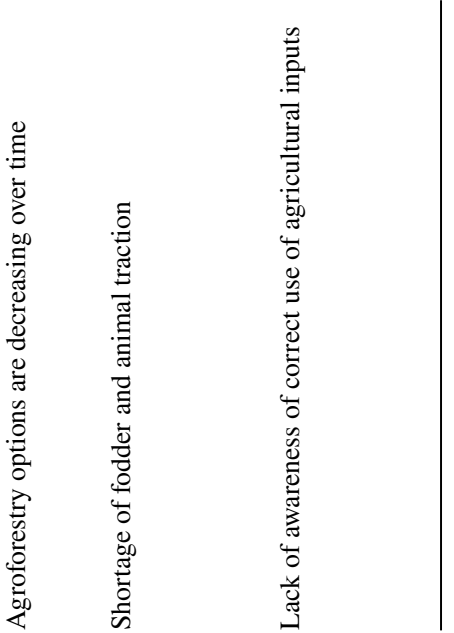




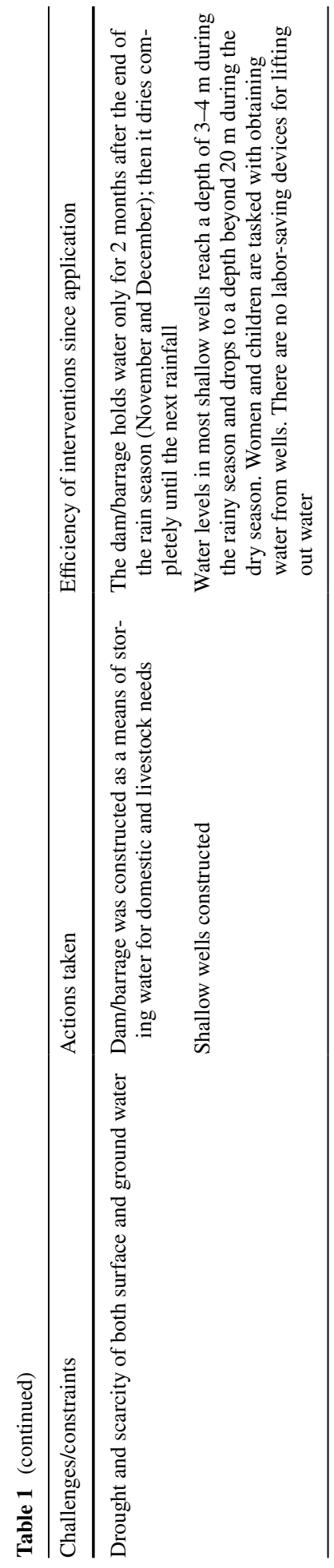


Kani watershed is a typical, dry West African landscape with low fertility soils and rangelands interspersed with patches of cropland growing dry-land cereals such as sorghum and maize along seasonal streams (Fig. 4). Of its total area of 5780 ha, cropland comprised 1933 ha in 1986 and 1637 ha in 1991. This increased to 2197 ha in 2002 and 2682 ha in 2014 (Table 2; Fig. 4). The area for growing cotton and maize increased from 346 ha (6\%) in 1986 to 390 ha (7\%) in 1991 and to 1621 ha (28\%) in 2014, and sorghum crop area increased from 1587 ha (27\%) in 1986 to 1883 ha (18\%) in 2014. This increase in agricultural area was mainly at the expense of rangelands which covered the total watershed at 66\% in 1986 and later reduced to 39\% in 2014 (Table 2; Fig. 4). This study confirms the findings by Ollenburger et al. (2016) who reported that in southern Mali expansion of cultivated land has taken place into previously uncultivated land due to reductions in fallowing time.

Using the 1986 data as a reference, representing the land use conditions during the beginning of SWC implementation in the study area, and comparing it with the 2014 land use data, it is understood that over the past 30 years, crop area in the watershed was increased almost twofold (from 33 to $61 \%$ ), whereas rangeland area was reduced by half (from 66 to 39\%). Using Eqs. 1 and 2, and an information table provided by McDaniels (1962) on the use coefficients and climate index, the CWU of crops (cotton dominant), sorghum and rangelands in mm per year was 615, 405 and 716, respectively. These estimates
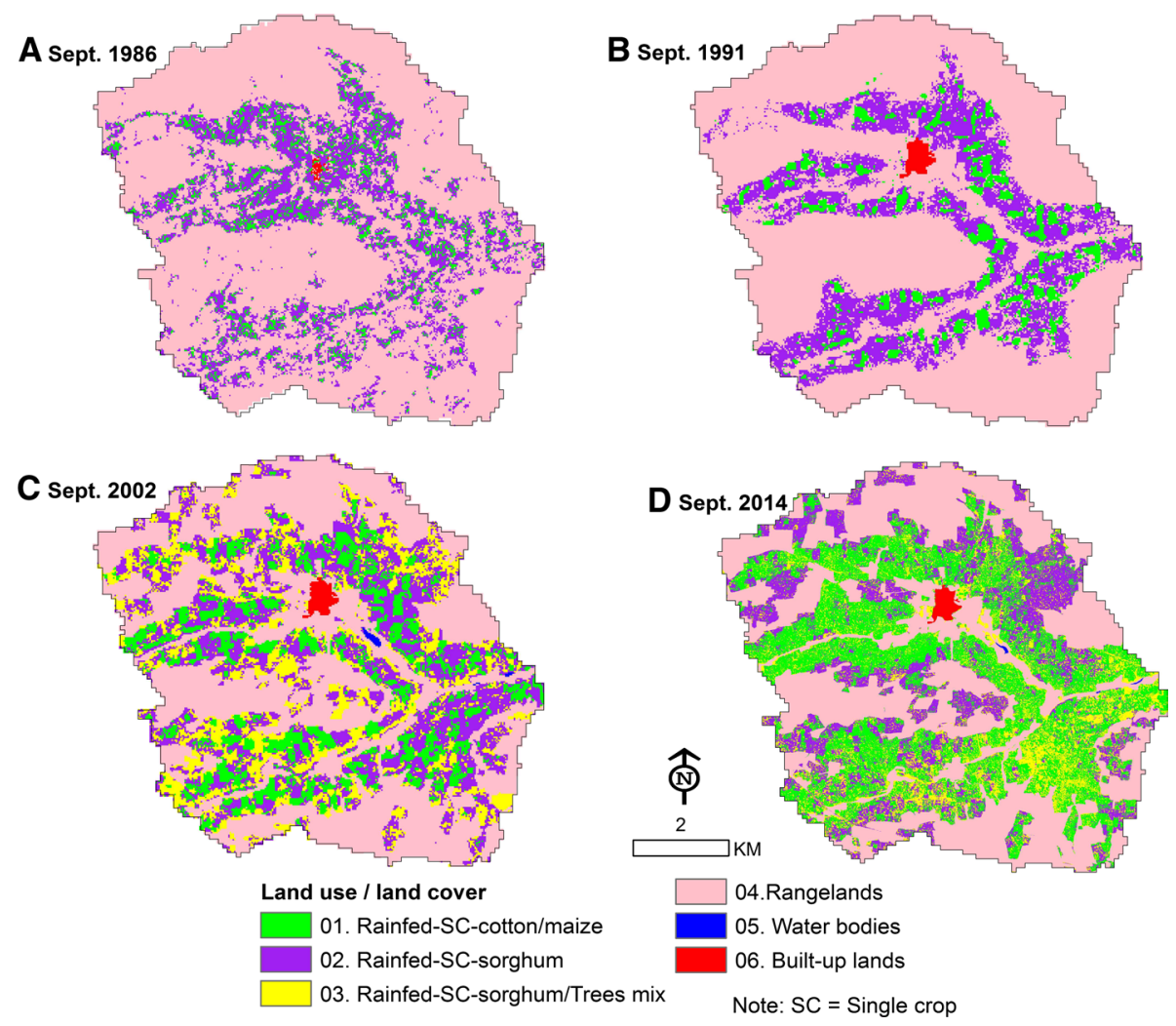

Fig. 4 Spatial extent of land uses for the year 1986, 1991, 2002 and 2014 in Kani watershed 
Table 2 Land use/land cover areas over the years for Kani watershed

\begin{tabular}{|c|c|c|c|c|c|c|c|c|}
\hline \multirow[t]{2}{*}{ LULC\# } & \multicolumn{2}{|l|}{ Nov 1986} & \multicolumn{2}{|l|}{ Sep 1991} & \multicolumn{2}{|l|}{ Sep 2002} & \multicolumn{2}{|l|}{ Sep 2014} \\
\hline & Area (ha) & $\%$ & Area (ha) & $\%$ & Area (ha) & $\%$ & Area (ha) & $\%$ \\
\hline 1. Rainfed single crop cotton/maize & 346 & 6 & 390 & 7 & 782 & 14 & 1621 & 28 \\
\hline 2. Rainfed single crop sorghum & 1587 & 27 & 1247 & 22 & 2424 & 42 & 1883 & 33 \\
\hline 3. Rangelands & 3840 & 66 & 4108 & 71 & 2531 & 44 & 2245 & 39 \\
\hline 4. Water bodies & & 0 & 0 & 0 & 7 & 0.001 & 2 & 0.001 \\
\hline 5. Built-up lands & 7 & 0.1 & 35 & 1 & 36 & 1 & 29 & 1 \\
\hline
\end{tabular}

were found to be comparable with the estimate provided by Critchley et al (1991) who reported that the CWU of cotton and sorghum was 627 and $398 \mathrm{~mm}$ per year, respectively. Published data on the water requirement for rangelands were not available. The total watershed CWU for the crop and rangeland is presented in Table 3 for the two land uses, i.e., 1986 and 2014.

According to Table 3, the total consumptive water use of field crops (cotton and sorghum) increased from 8.55 million $\mathrm{m}^{3}$ per year to 17.60 million $\mathrm{m}^{3}$ per year (97.5\%) from 1986 to 2014, whereas the consumptive water use for rangelands reduced from 27.49 million $\mathrm{m}^{3}$ per year to 16.07 million $\mathrm{m}^{3}$ per year $(41.54 \%)$ for the same period. The difference in CWU between field crops to rangelands is increasing over the past 30 years. Theoretically, this differential increase is an increase in evapotranspiration from field crops and is essential to gain more yield at the expense of clearing the rangelands. Sorghum yield and production data from faostat3.fao.org (last accessed 30/05/2017) for southern Mali however showed that yield was under one ton per hectare for most of the years from 1980 to 2014 (Fig. 5). The increase in production of sorghum from the period 1980 to 2009 and cotton from the period 1980 to 1998 was due to an increase in cropping areas (Figs. 5, 6), i.e., agricultural extensification.). Cotton production reduced after 1998 as the support provided by CMDT discontinued. According to Nin-Pratt (2015) agricultural extensification is defined as 'the expansion of production into previously uncultivated areas.' The contrast to this is, intensification which is defined as 'a process that results in increased output per unit of land as a consequence of intensive use of inputs and labor (per unit land).' A study by Ollenburger et al. (2016) in southern Mali confirmed that agricultural intensification

Table 3 Computed CWU for specific crops over a period of land use

\begin{tabular}{llllll}
\hline Year & Land use & Area (ha) & $\begin{array}{l}\text { CWU (mm/ } \\
\text { year) }\end{array}$ & $\begin{array}{l}\text { Total } \mathrm{CWU}^{\mathrm{a}}(\mathrm{mil}- \\
\left.\text { lion } \mathrm{m}^{3} / \mathrm{year}\right)\end{array}$ & $\begin{array}{l}\text { Total CWU by } \\
\text { cover (million } \mathrm{m}^{3} / \\
\text { year) }\end{array}$ \\
\hline \multirow{2}{*}{1986} & Cotton & 346 & 615 & 2.12 & 8.55 \\
& Sorghum & 1587 & 405 & 6.43 & \\
& Rangeland & 3840 & 716 & 27.49 & 27.49 \\
& Cotton & 1621 & 615 & 9.97 & 17.60 \\
& Sorghum & 1883 & 405 & 7.63 & 16.07 \\
\hline
\end{tabular}

${ }^{\mathrm{a}}$ Total $\mathrm{CWU}=\mathrm{CWU} \times 10^{-3} \times$ Area $\times 10^{4}$ 


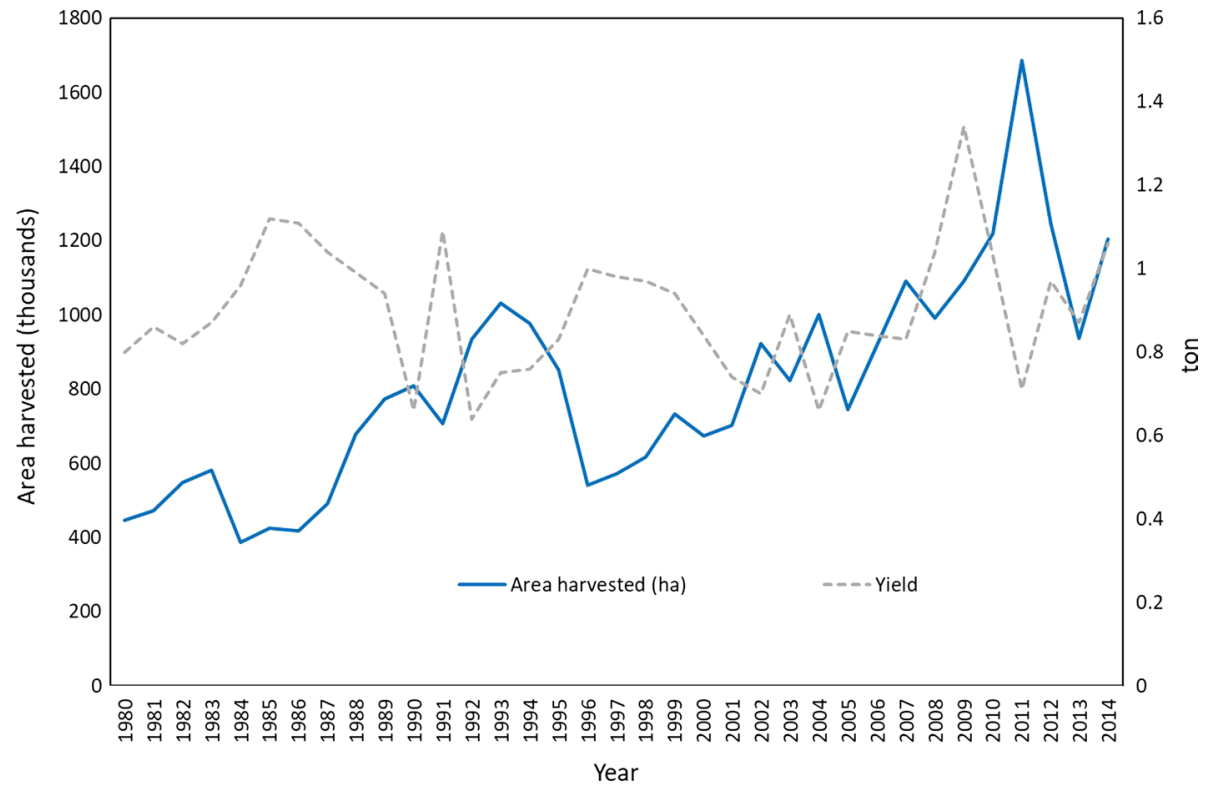

Fig. 5 Area of production and yield of sorghum in southern Mali over 30 years

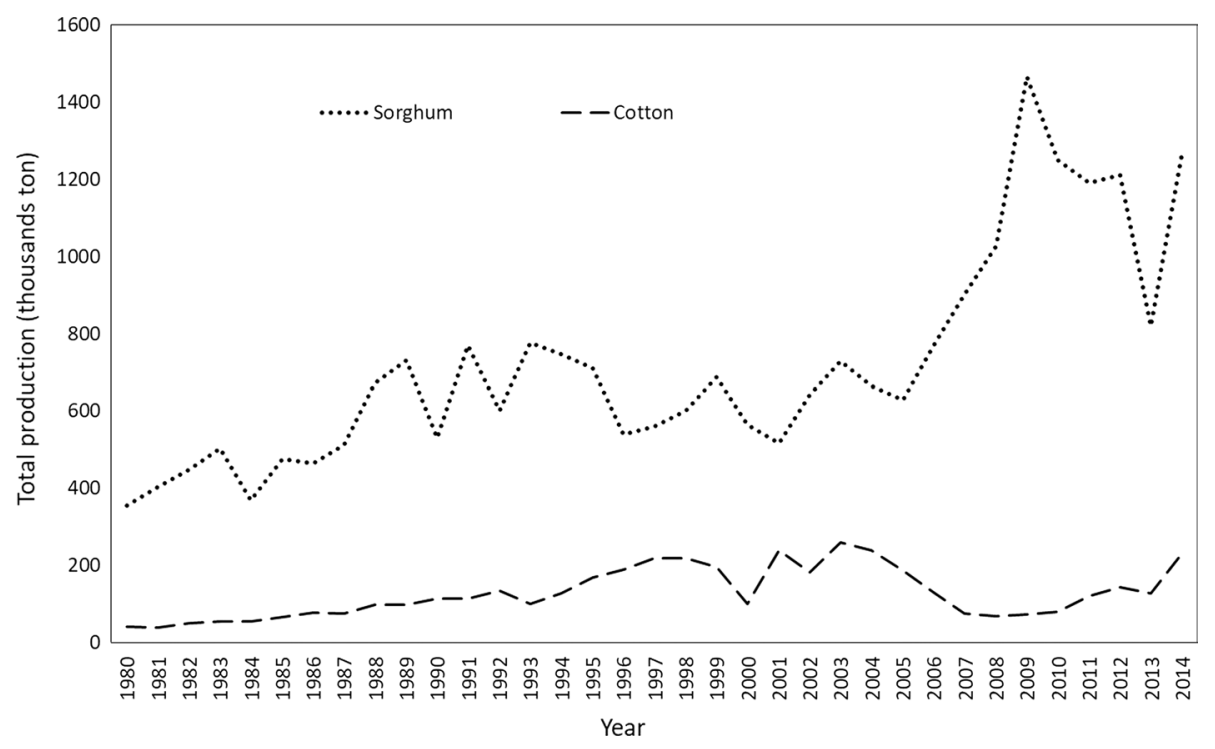

Fig. 6 Total production of sorghum and cotton crop in southern Mali over 30 years

program by CMDT did not result in an increase in crop yield, with average yields of maize and cotton stagnating at 1600 and $900 \mathrm{~kg} / \mathrm{ha}$, respectively, over long periods. This shows that neither intensification nor extensification has brought significant yield increase in southern Mali over a long period. One possible reason could be the inadequacy of soil 
moisture to meet the water requirements of crops created by poor agronomic practices and drought. In such cases, more SWC practices can help provide the additional soil moisture required to increase crop yield.

\subsection{Evaluating the impact of SWC practices on runoff volume and soil moisture dynamics}

\subsubsection{Runoff volume}

The impact of SWC practices was evaluated on runoff generation and soil moisture dynamics in the watershed. Runoff hydrographs were plotted for 2 years (2015 and 2016) from the experimental station that consisted of treatment and control fields (Figs. 7a, b). Generally, the runoff hydrograph followed the rainfall pattern without any lag time, indicating rapid watershed response and poor drainage conditions during the beginning of rainfall events. The spiked response of generated runoff particularly in the control field indicated rapid runoff from farmers' fields. The hydrograph pattern for the control and treatment fields showed a consistent pattern, i.e., peak flow responding to higher magnitude of rainfall and a drawdown in hydrograph when rainfall amount was low (Figs. 7a, b).

Mean runoff rates from both control and treatment fields were higher in 2015 than in 2016 with a difference of $37 \%$ ( $p$ value 0.001 ). This difference can be explained by the higher rainfall intensity in 2015. In 2015, high rainfall $(850 \mathrm{~mm})$ was recorded in shorter period (34 days) than in 2016 (729 mm in 38 days). Similarly, over the 2 years, mean runoff from the control field was $73 \%$ higher ( $p$ value 0.005 ) in the control field than the treatment field (Table 4).

Two rainfall events in the same month were analyzed separately to understand the watershed response at the beginning of the rainy season. An instantaneous minimum rainfall of $4.75 \mathrm{~mm}$ (recorded on July 26, 2015) became runoff at a rate of $7.5 \%$ and $33.42 \%$ in the treatment and control fields, respectively. However, with the season's peak rainfall event $91 \mathrm{~mm}$ (recorded on July 6, 2015) runoff was 33\% from the treatment field and 43.6\% from the control field. The rainfall quantity and its intensity and land cover have implications in terms of continued mining of farm nutrients, particularly during the beginning of the rainfall event.

The results show that SWC practices combat the severity of erosion in the study area by reducing the runoff amount and increasing infiltration into the subsurface. Additional benefits of SWC include improvements in crop yields. A recent study by Traoré et al. (2017) revealed that the use of contour bunding technique in an experimental station located at Cinzana $\left(13^{\circ} 53^{\prime} \mathrm{N}\right.$ and $\left.5^{\circ} 63^{\prime} \mathrm{W}\right)$ in southern Mali increased the yields of sorghum and millet by 58 and $72 \%$, respectively.

\subsubsection{Soil moisture dynamics}

Soil moisture in the present study refers to the available water content at different soil depth. A soil water content at dry condition, which is also called a permanent wilting point (WP) was initially measured at different soil depth. For a $100 \mathrm{~cm}$ soil depth, the permanent WP record was $2.71 \%$. Similarly, the field capacity (FC) of the soil also varied along with the soil depth and the FC value at $100 \mathrm{~cm}$ soil depth was $45.90 \%$. A general observation of soil moisture dynamics in the watershed revealed that soil water availability was always greater in areas where fields had been treated with SWC practices. Over the 2 years (2015 

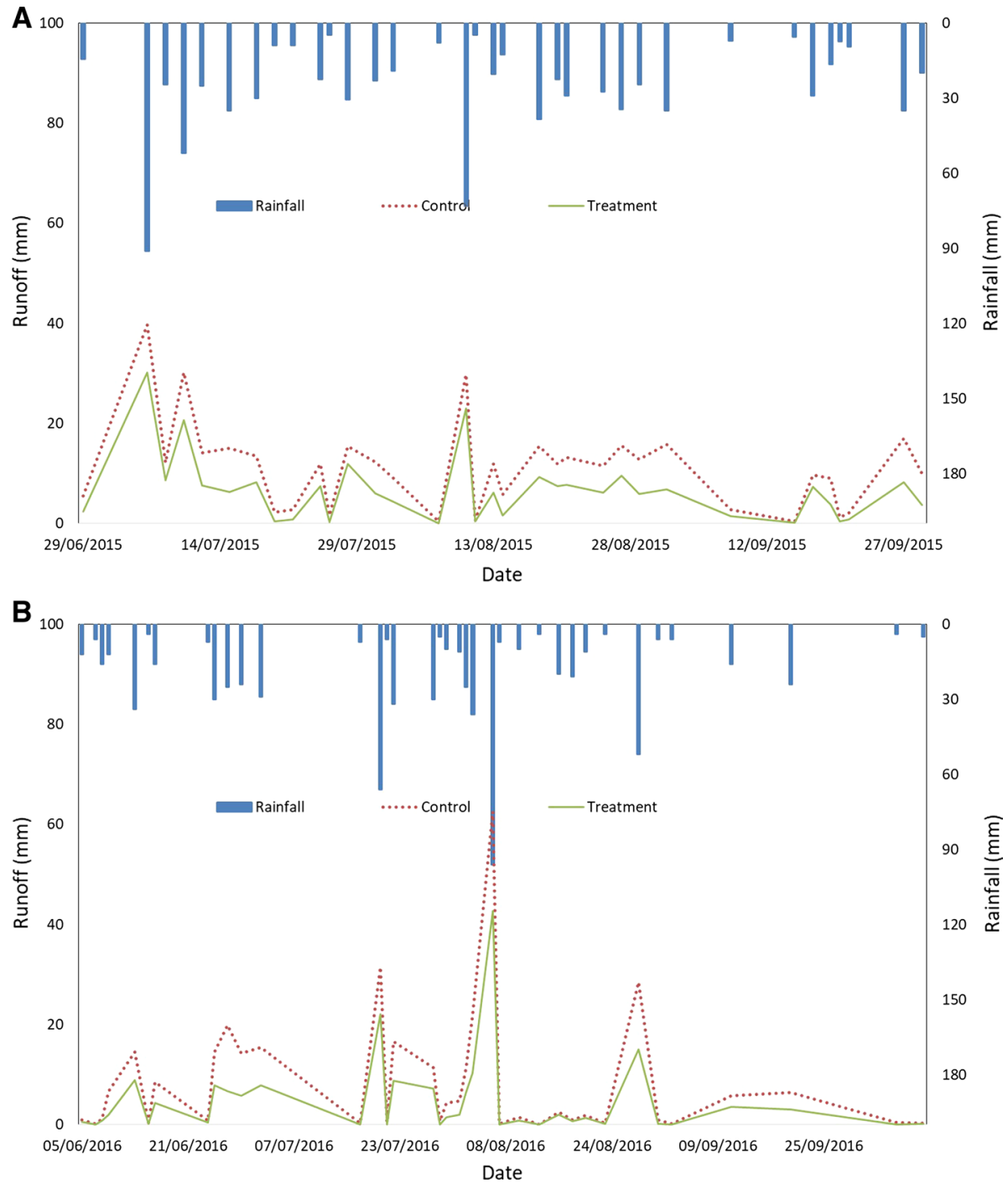

Fig. 7 a Rainfall and runoff hydrograph from experimental station in Kani watershed in 2015. b Rainfall and runoff hydrograph from experimental station in Kani watershed in 2016

Table 4 Runoff rate in an experimental station

\begin{tabular}{lllll}
\hline Year & Control & Treatment & Mean & Rainfall \\
\hline 2015 & 11.30 & 6.70 & $9.0 \mathrm{a}$ & 850 \\
2016 & 8.42 & 4.71 & $6.56 \mathrm{~b}$ & 729 \\
Mean & $9.86 \mathrm{a}$ & $5.71 \mathrm{~b}$ & & \\
& $p$ value 0.005 & & $p$ value 0.001 & \\
\hline
\end{tabular}

Values with different letters are statistically different at $p=0.01$ 
and 2016), soil moisture was consistently higher $(p<0.005)$ in fields treated with SWC practices (Table 5). Further study of seasonal variation of soil moisture revealed that in July at the beginning of the rainy season, maximum soil moisture $(25 \%)$ was observed in the first $40 \mathrm{~cm}$ of soil layer (July 3, 2015) after which water content decreased and stayed stable until $80 \mathrm{~cm}$ depth and finally reached about $18 \%$ for the treatment plot and $10 \%$ for the control field at $100 \mathrm{~cm}$ depth (Fig. 8). In the middle of the rainy season, maximum soil moisture (35\%) was observed in treated fields until a depth of $80 \mathrm{~cm}$ from August 02 to September 21 when rainfall events were still frequent and drainage continued to be deeper. At the end of the season, drainage was deep with less water (about $20 \%$ at $60 \mathrm{~cm} \mathrm{depth}$ ). However, soil moisture was at least $25 \%$ explaining the real water supply possibility for the park land trees (Fig. 8).

Similar observations were found at the second experimental station (Fig. 9), where soil moisture was always greater in the treated field than in the control field. In July, at the beginning of the rainy season, maximum average soil moisture of $19.6 \%$ was observed in the first $80 \mathrm{~cm}$ of soil layer (July 3, 2015). With $196 \mathrm{~mm}$ of rainfall during the next 10 days, a uniform gradient of soil moisture was observed with a maximum of $32 \%$ at $100 \mathrm{~cm}$ depth. In the middle of the rainy season, the maximum soil moisture was $35 \%$ at $80 \mathrm{~cm}$ depth for both treatment and control fields. At the end of the rainy season, the treatment field displayed higher soil water content in the upper $80 \mathrm{~cm}$ soil layer compared to the control field. This explains why in general fields treated with SWC allow better crop maturity during terminal dry spell conditions.

Mean soil moisture content in 2015 was $36 \%$ higher $(p<0.0001)$ than the mean value in 2016 (Table 5). This situation can be explained by the rainfall amount which was $17 \%$ greater in 2015 than 2016. Soil moisture showed highly significant difference $(p<0.0001)$ along the soil profile at different depths. In fact, soil moisture did not vary statistically from 60 and $100 \mathrm{~cm}$ depths where it represented the highest value, at $10 \mathrm{~cm}$ depth soil moisture was the lowest (Table 5). This can be explained by the utilization of soil moisture by plant roots for their growth. A statistically different increasing trend of soil moisture presence was observed downward the soil horizon.

Soil moisture variations along the soil horizon revealed that at the beginning of the rainfall event (July) relatively similar soil moisture was observed in both treatment and control fields in the depth range of 40-80 cm. Divergence in soil moisture values was observed as rain continued in the mid-rainy season (August and September) and further toward the end of the rainfall event. A relative change in soil moisture divergence values for the depths in both control and treatment fields revealed that on August 2, 2015 (mid-rainy season), the divergence values were 26.4, 25.6, 13 and $32.9 \%$ for the depths of 20,40, 60 and $80 \mathrm{~cm}$, respectively. On November 10, 2015 (the end of rainy season) the corresponding divergence values for these depths were 70, 48.3, 47.7 and 85\%, respectively. This shows that a SWC practice like that of contour bunding could ensure presence of more soil moisture to meet the crops' water requirement and hence increased crop yield. In addition, as rainfall events increased, with SWC practices, deeper percolation was attained to sufficiently recharge shallow aquifers. This recharge is necessary for the survival of trees during the hot and dry season.

\subsection{Economic benefits of SWC practices}

The results derived from partial budget analysis for sorghum production with and without CBT are presented in Table 6. Economic analysis for cotton production was not included in the study as cotton production sales are determined by CMDT. CMDT has a monopoly 


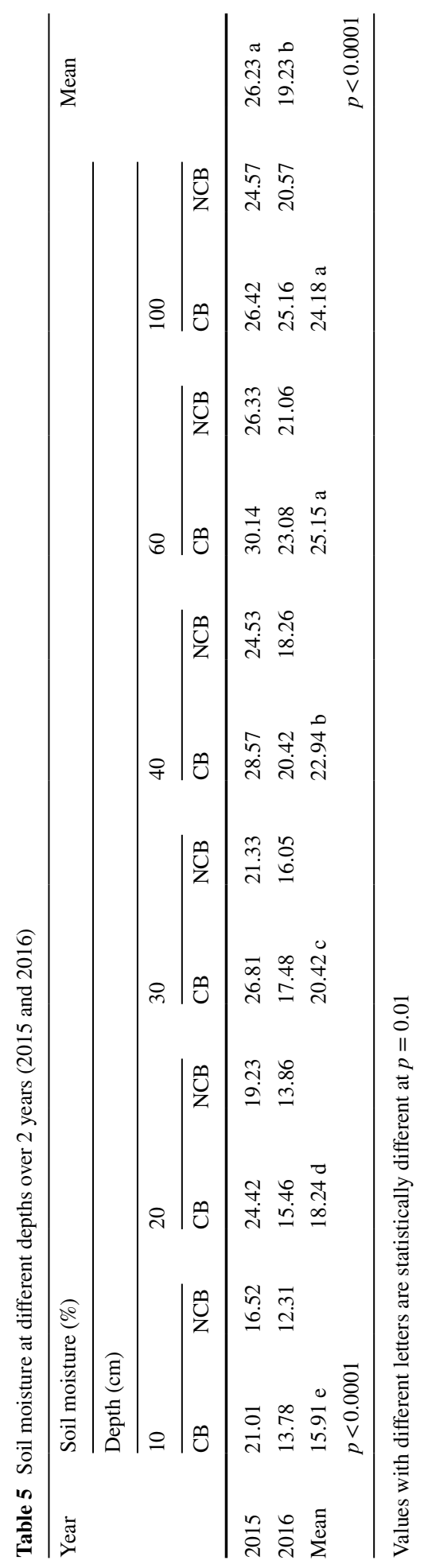




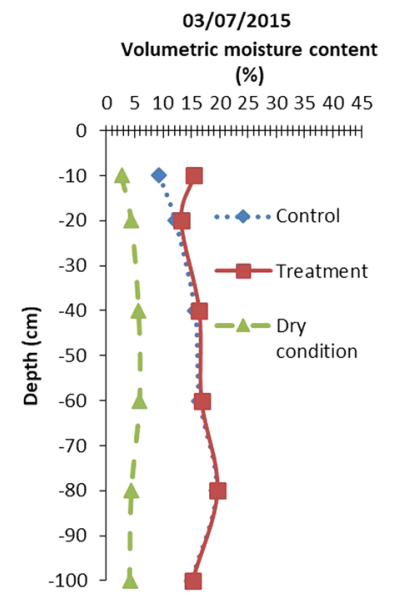

$02 / 08 / 2015$

Volumetric moisture content

$0 \quad 51015202530354045$

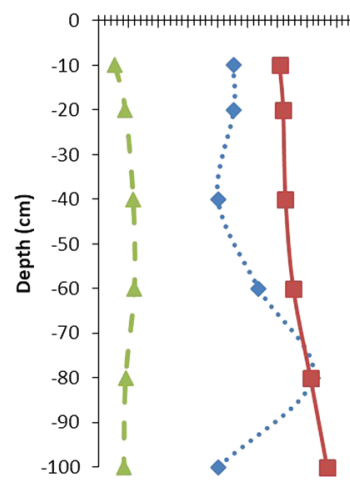

$11 / 10 / 2015$

Volumetric moisture content

(\%)

$0 \quad 51015202530354045$

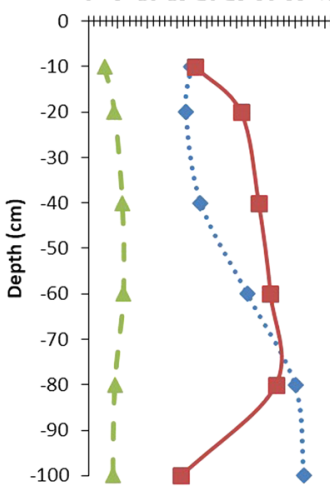

$13 / 07 / 2015$

Volumetric moisture content

(\%)

$0 \quad 51015202530354045$

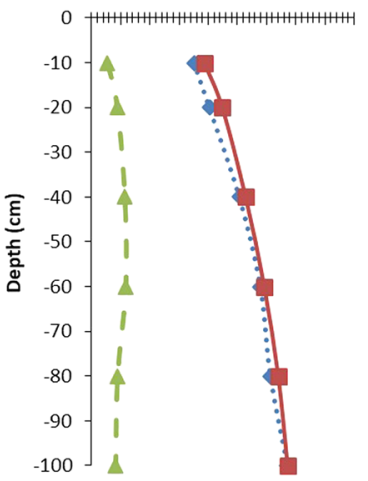

22/08/2015

Volumetric moisture content (\%)

$0 \quad 5 \quad 1015202530354045$

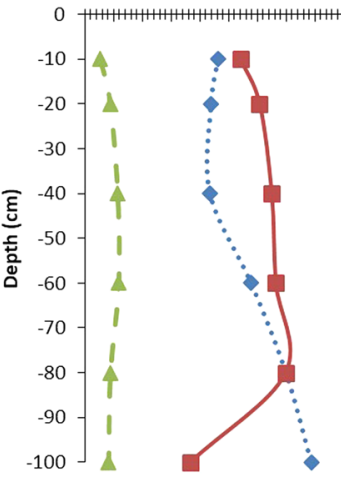

31/10/2015

Volumetric moisture content (\%)

$0 \quad 51015202530354045$

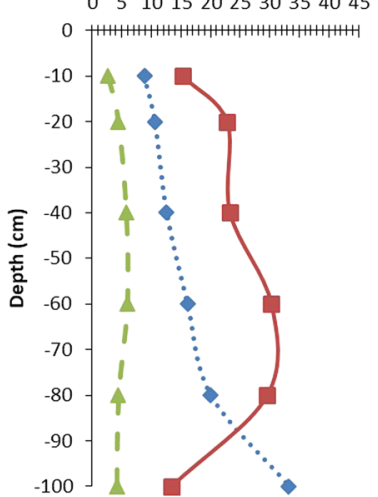

23/07/2015

Volumetric moisture content (\%)

0 $5 \quad 1015202530354045$

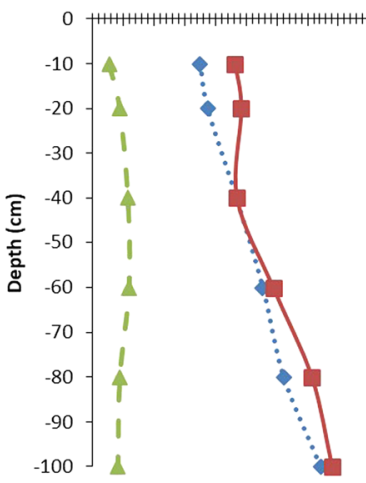

21/09/2015

Volumetric moisture content

(\%)

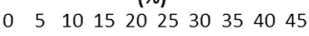

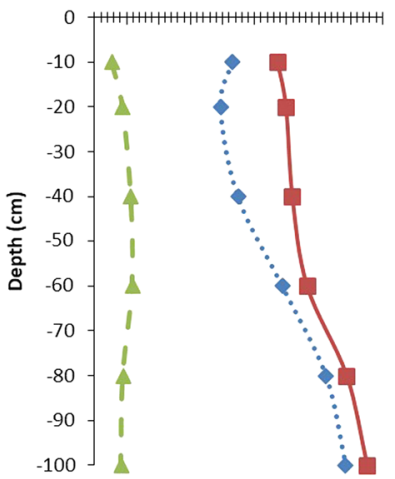

10/11/2015

Volumetric moisture content (\%)

$0 \quad 5 \quad 1015202530354045$

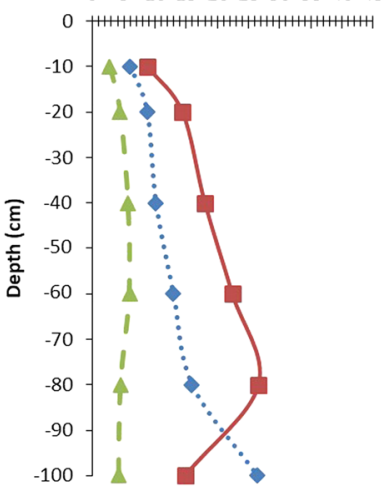

Fig. 8 Vertical distribution of soil moisture in the first experimental field. The $x$-axis denotes the soil moisture in volumetric water content (\%); the $y$-axis denotes the depth from the ground surface to various soil moisture layers 
03/07/2015

Volumetric moisture content

(\%)

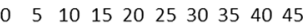

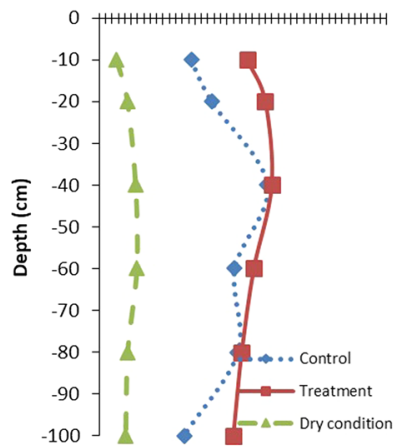

$02 / 08 / 2015$

Volumetric moisture content

(\%)

$\begin{array}{llllllllll}0 & 5 & 10 & 15 & 20 & 25 & 30 & 35 & 40 & 45\end{array}$

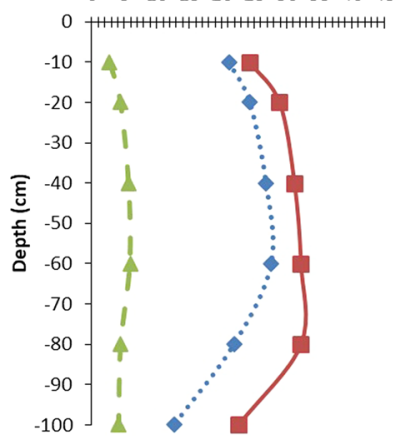

$11 / 10 / 2015$

Volumetric moisture content (\%)

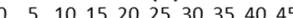

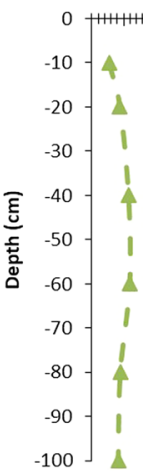

$13 / 07 / 2015$

Volumetric moisture content

(\%)

$23 / 07 / 2015$

Volumetric moisture content

(\%)

$0 \quad 51015202530354045$

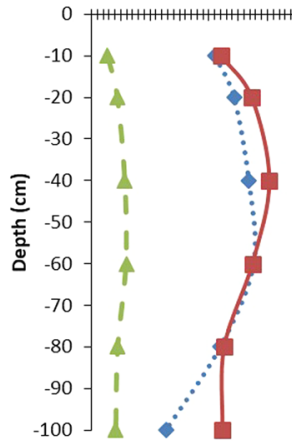

22/08/2015

Volumetric moisture content

(\%)

0 51015202530354045

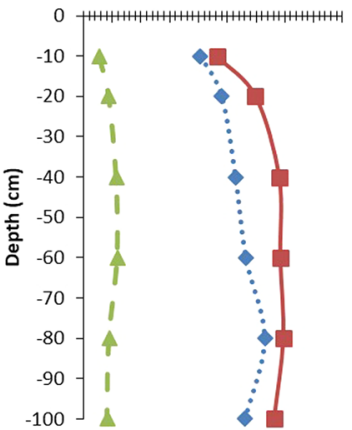

$31 / 10 / 2015$

Volumetric moisture content (\%)

$0 \quad 51015202530354045$

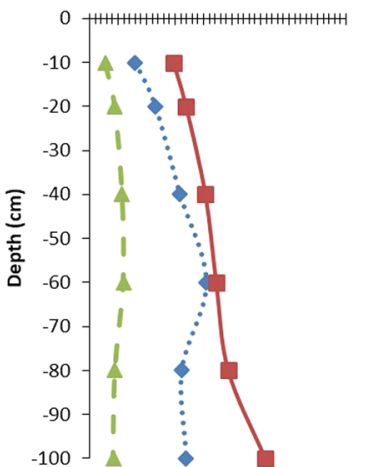

$0 \quad 5 \quad 1015202530354045$

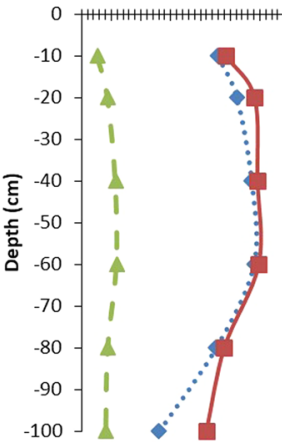

$21 / 09 / 2015$

Volumetric moisture content (\%)

$0 \quad 5 \quad 1015202530354045$

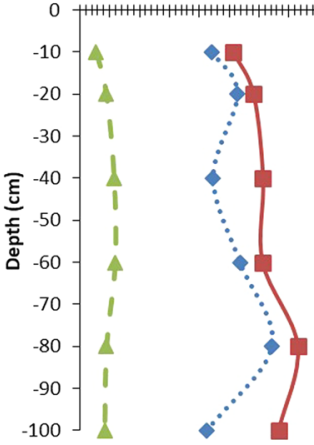

10/11/2015

Volumetric moisture content (\%)

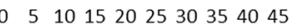

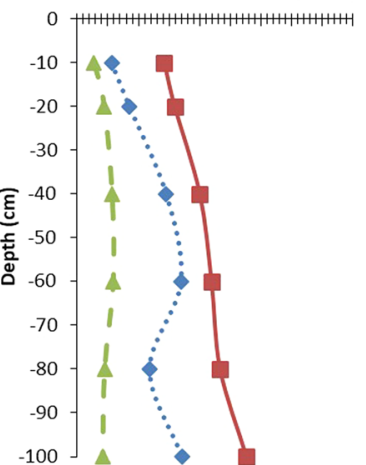

Fig. 9 Vertical distribution of soil moisture in the second experimental field. The $x$-axis denotes the soil moisture in volumetric water content (\%); the $y$-axis denotes the depth from the ground surface to various soil moisture layers 
on sale of seed and purchases of cotton, and fixes prices at the beginning of the season. Through CMDT-associated cooperatives formed in the 1990s, farmers are able to procure inputs on credit, with payment from cotton earnings at the end of the season (Ollenburger et al. 2016). The cost-benefit analysis for sorghum production with CBT generated a net benefit of FCFA 149,400 (USD 249) per hectare with a production cost of FCFA 39,600 (USD 66). The production without contour bunding generated a net benefit of FCFA 120,665 (USD 201) per hectare with a production cost of FCFA 34,000 (USD 57). This implies that the net benefit generated by the sorghum production with contour bunding is about $20 \%$ higher than that generated without contour bunds. The marginal rate of returns of changing from without CBT to CBT treatment is 5.13. This means that a farmer's investment of 1 FCFA in the application of CBT on sorghum returns the invested 1 FCFA and gives an additional benefit of 5.13 FCFA.

\section{Conclusions and recommendations}

The aridity and low potential for surface water storage from runoff suggest that subsurface water management through SWC practices may be a viable option to improve the current

Table 6 Partial budget for sorghum production with and without contour bunding system

\begin{tabular}{|c|c|c|}
\hline & $\begin{array}{l}\text { Without contour } \\
\text { bunding }\end{array}$ & $\begin{array}{l}\text { With } \\
\text { contour } \\
\text { bunding }\end{array}$ \\
\hline \multicolumn{3}{|l|}{ Gross farm gate benefits } \\
\hline Average grain yield (kg/ha) & 1076 & 1308 \\
\hline Average residue yield (kg/ha) & 1245 & 1550 \\
\hline Adjusted grain yield (kg/ha) & 968 & 1177 \\
\hline Adjusted residue yield (kg/ha) & 1121 & 1395 \\
\hline Grain price (FCFA/kg) & 125 & 125 \\
\hline Residues price (FCFA/kg) & 30 & 30 \\
\hline Gross farm gate benefits (FCFA/ha) & 154,630 & 188,975 \\
\hline \multicolumn{3}{|l|}{ Variable input costs $(F C F A / h a)$} \\
\hline Compost & 5500 & 6000 \\
\hline Seeds & 2400 & 2400 \\
\hline Harvest bags & 2500 & 3000 \\
\hline Urea & 16,700 & 17,500 \\
\hline Labor & 2200 & 3700 \\
\hline Workforce & 4700 & 7000 \\
\hline Total variable input costs (FCFA/ha) & 34,000 & 39,600 \\
\hline \multicolumn{3}{|l|}{ Net benefit } \\
\hline Net benefit (FCFA/ha) & 120,665 & 149,400 \\
\hline Change in net benefits between two consecutive treatments (FCA/ha) & & 28,735 \\
\hline $\begin{array}{l}\text { Change in total variable input costs between two consecutive treatments } \\
\text { (FCFA/ha) }\end{array}$ & & 5600 \\
\hline \multicolumn{3}{|l|}{ Marginal rate of return } \\
\hline Marginal rate of return & & 5.13 \\
\hline
\end{tabular}


agricultural productivity in southern Mali. The present trend is to clear the natural vegetation in search for more agricultural fields. This has resulted in severe land degradation with loss of topsoil and washing away of useful nutrients from many of the agricultural fields. Ollenburger et al. (2016) highlighted that in southern Mali, cropland expansion is likely to continue and with increase in population, land is becoming scarcer. The result of crop- land expansion is an increasing amount of consumptive water use by field crops and if adequate SWC practices are not in place the water requirement of crops will not be met and the current low agricultural productivity will continue. This is a concern for natural resources management and sustained agricultural productivity in southern Mali. An increase in crop production (without yield increase per hectare) at the expense of natural vegetation is an alarming threat. Using a field experimentation of two agronomic seasons' data (2015 and 2016) we were able to show that with the implementation of contour bunding technique as an SWC practice, runoff volume and soil erosion were significantly reduced, allowing for more soil moisture during the different seasons of rainfall events. Soil moisture values were significantly higher along the soil depth and over the years. In a separate study, Traoré et al. (2017) reported a significant yield improvement (58\% for millet and $72 \%$ for sorghum) in farmers' fields treated with contour bunding technique in southern Mali. The net returns with the use of contour bunding were higher by $20 \%$ and in addition the willingness of farmers to pay 5000 FCFA per hectare to have a contour bunding in their farm land to a local NGO makes the investment socially viable. In conclusion, farm activities in the watershed need to ensure the presence of adequate soil moisture to meet crops' water requirement and preservation of farm nutrients through implementation of more SWC practices. The hydrological impacts of SWC practices in Kani watershed can be monitored for a longer period using the established community-managed monitoring networks, which provided a low-cost and highly useful source of hydro-meteorological data.

Acknowledgements This work was supported by the CGIAR program on Water, Land and Ecosystem (WLE) and the Africa Research in Sustainable Intensification for the Next Generation (Africa RISING) program in Mali. Authors are very grateful to the financial support provided by the International Water Management Institute (IWMI) and the US Agency for Development (USAID) through the International Institute of Tropical Agriculture (IITA). Authors would like to thank Mr. Cedrick Guedessou and Kani watershed community in availing data for the study. We are also thankful to the anonymous reviewer whose valuable comment improved the quality of the manuscript.

Open Access This article is distributed under the terms of the Creative Commons Attribution 4.0 International License (http://creativecommons.org/licenses/by/4.0/), which permits unrestricted use, distribution, and reproduction in any medium, provided you give appropriate credit to the original author(s) and the source, provide a link to the Creative Commons license, and indicate if changes were made.

\section{References}

Akinseye, F. M., Agele, S. O., Traore, P. C. S., Adam, M., \& Whitbread, A. M. (2016). Evaluation of the onset and length of growing season to define planting date- A case study for Mali (West Africa)'. Theoretical and Applied Climatology, 124, 973. https://doi.org/10.1007/s00704-015-1460-8.

Bayabil, H. K., Tebebu, T. Y., Stoof, C. R., \& Steenhuis, T. S. (2016). Effects of a deep-rooted crop and soil amended with charcoal on spatial and temporal runoff patterns in a degrading tropical highland watershed. Hydrology and Earth System Sciences, 20, 875-885.

Berg, M. D., Marcantonio, F., Allison, M. A., McAlister, J., Wilcox, B. P., \& Fox, W. E. (2016). Contrasting watershed-scale trends in runoff and sediment yield complicate rangeland water resources planning. Hydrology and Earth System Sciences, 20, 2295-2307. 
Berihun, M. L., Melesse, A. M., \& Zemadim, B. (2016). Spatiotemporal variability of hydrological variables of Dapo watershed, Upper Blue Nile Basin, Ethiopia. In A. M. Melesse \& W. Abitew (Eds.), Landscape dynamics, soils and hydrological processes in varied climates (pp. 141-161). Berlin: Springer Geography.

Birhanu, Z. B., \& Tabo, R. (2016). Shallow wells, the untapped resource with a potential to improve agriculture and food security in southern Mali. Agriculture \& Food Security, 5, 5.

Blackie, J. R., \& Robinson, M. (2007). Development of catchment research, with particular attention to Plynlimon and its forerunner, the East African catchments. Hydrology and Earth System Sciences, 11, 26-43.

Blaney, H. F., \& Criddle, W. D. (1950). Determining water requirements in irrigated areas from climatological and irrigation data. U. S. soil conservation service technical paper 96.

Blume, T., Zehe, E., \& Bronstert, A. (2007). Use of soil moisture dynamics and patterns for the investigation of runoff generation processes with emphasis on preferential flow. Hydrology and Earth System Sciences Discussions, 4, 2587-2624.

Bodnar, F. (2005). Monitoring for impact: Evaluating 20 years of soil and water conservation in southern Mali. Tropical resources management papers, No. 71 (2005). ISBN 90-6754-963-0 (pp. 229). Available http://www.dow.wau.nl/aswc. Accessed 25 June 2017.

Butt, T. A., McCarl, B. A., Angerer, J., Dyke, P. T., \& Stuth, J. W. (2005). The economic and food Security implications of climate change in Mali'. Climate Change, 68, 355-378.

Critchley, W., Siegert, K., \& Chapman, C. (1991). A manual for the design and construction of water harvesting scheme for plant production. Food and Agricultural Organization of the United NationsRome. Water harvesting manual (AGL/MISC/17/91). http://www.fao.org/docrep/U3160E/u3160 e00.htm\#Contents. Last accessed 25 June 2017.

Doraiswamy, P. C., McCarty, G. W., Jr Hunt, E. R., Yost, R. S., Doumba, M., \& Franzluebbers, A. J. (2007). Modeling soil carbon sequestration in agricultural lands of Mali. Agricultural Systems, 94, 63-74.

Duvert, C., Gratiot, N., Némery, J., Burgos, A., \& Navratil, O. (2011). Sub-daily variability of suspended sediment fluxes in small mountainous catchments \& ndash implications for community-based river monitoring. Hydrology and Earth System Sciences, 15, 703-713.

Ebi, K. L., Jonathan, P., Mamadou, P., Alpha, K., Joel, S., \& Tanveer, B. (2011). Smallholders adaptation to climate change in Mali'. Climate Change, 108, 423-436. https://doi.org/10.1007/s10584-011-0160-3.

EPA. (2012). United States Environmental Protection Agency. http://www.water.epa.gov/type/water shed/. Accessed 26 November 2015.

Falconnier, G. N., Descheemaeker, K., Van Mourik, T. A., \& Giller, K. E. (2016). Unravelling the causes of variability in crop yields and treatment responses for better tailoring of options for sustainable intensification in southern Mali. Field Crops Res, 187, 113-126.

Garg, K. K., Karlberg, L., Barron, J., Wani, S. P., \& Rockström, J. (2011). Assessing impact of agricultural water interventions at the Kothapally watershed, southern India. Hydrological Processes, 26(3), 387-404.

Garg, K. K., Wani, S. P., Barron, J., Karlberg, L., \& Rockström, J. (2012). Up-scaling potential impacts on water flows from agricultural water interventions: Opportunities and trade-offs in the Osman Sagar catchment, Musi sub-basin, India. Hydrological Processes, 27(26), 3905-3921.

German, L. A., Berhane, K., \& Kindu, M. (2005). Watershed management to counter farming systems decline. Towards a demand-driven systems-oriented research agenda, Agricultural Research \& Extension Network. AgREN network paper, open file report, 145 (pp. 16)

Gigou, J., Traoré, K., Giraudy, F., Coulibaly, H., Sogoba, B., \& Doumbia, M. (2006). Aménagement paysan des terres et réduction du ruissellement dans les savanes africaines. Cahiers Agricultures, 15, 116-122.

Giller, K. E., Tittonell, P., Rufino, M. C., van Wijk, M. T., Zingore, S., Mapfumo, P., et al. (2011). Communicating complexity: Integrated assessment of trade-offs concerning soil fertility management within African farming systems to support innovation and development. Agricultural Systems, 104, 191-203.

Gomani, M. C., Dietrich, O., Lischeid, G., Mahoo, H., Mahay, F., Mbilinyi, B., et al. (2010). Establishment of a hydrological monitoring network in a tropical African catchment: An integrated participatory approach. Physics and Chemistry of the Earth, 35(13-14), 648-656.

Gumma, M. K., Birhanu, Z. B., Irshad, A. M., Tabo, R., \& Whitbread, A. M. (2016). Prioritization of watersheds across Mali using Remote sensing data and GIS techniques for agricultural development planning. Water, 8(6), 260.

Gumma, M. K., Rooijen, D. V., Nelson, A., Thenkabail, P., Aakuraju, R., \& Amerasinghe, P. (2012). Expansion of urban area and wastewater irrigated rice area in Hyderabad, India. Irrigation and Drainage Systems, 25(3), 135-149. 
Gumma, M. K., Thenkabail, P. S., Hideto, F., Nelson, A., Dheeravath, V., Busia, D., et al. (2011). Mapping irrigated areas of Ghana using fusion of $30 \mathrm{~m}$ and $250 \mathrm{~m}$ resolution remote-sensing data. Remote Sensing, 3(4), 816-835.

Jarvis, A., Reuter, H. I., Nelson, A., \& Guevara, E. (2008). Hole-filled seamless SRTM data V4. International Centre for Tropical Agriculture (CIAT). http://srtm.csi.cgiar.org/,2008. Accessed 04 June 2015.

Joshi, P. K., Jha, A. K., Wani, S. P., Sreedevi, T. K., \& Shaheen, F. A. (2008). Impact of watershed program and conditions for success: A meta-analysis approach. Global theme on agro-ecosystems. International Crops Research Institute for the Semi-Arid Tropics and National Centre for Agricultural Economics and Policy Research. Shah, Intermediate Technology Publications Ltd, London, UK, Open File Report 46 (pp. 354-368).

Kongo, M. V., Kosgei, R. J., Jewitt, W. P. G., \& Lorentz, A. S. (2010). Establishment of a catchment monitoring network through a participatory approach in a rural community in South Africa. Hydrology and Earth System Sciences, 14, 2507-2525.

Kumar, S., Ramilan, T., Ramarao, C. A., Srinivasa Rao, C., \& Whitbread, A. (2016). Farm level rainwater harvesting across different agro climatic region of India: Assessing performance and its determinants. Agricultural Water Management, 176, 55-66.

Lathuillière, M. J., Coe, M. T., \& Johnson, M. S. (2016). A review of green- and blue-water resources and their trade-offs for future agricultural production in the Amazon Basin: What could irrigated agriculture mean for Amazonia? Hydrology and Earth System Sciences, 20, 2179-2194.

Liu, J., Zehnder, A. J. B., \& Yang, H. (2009). Global consumptive water use for crop production: The importance of green water and virtual water. Water Resources Research, 45(5), W05428.

McCartney, M., \& Smakhtin, V. (2010). Water storage in an era of climate change: Addressing the challenge of increasing rainfall variability. IWMI Blue paper, Open File, (p. 24).

McCormack, T., Naughton, O., Johnston, P. M., \& Gill, L. W. (2016). Quantifying the influence of surface water-groundwater interaction on nutrient flux in a lowland karst catchment. Hydrology and Earth System Sciences, 20, 2119-2133.

McDaniels, L. L. (1962). Consumptive use of water by major crops in Texas. Bulletin 6019 (p. 49).

Nin-Pratt, A. (2015). Agricultural intensification in Africa: A regional analysis (No. 01433), IFPRI discussion paper. International Food Policy Institute, Washington, DC.

Ollenburger, M. H., Descheemaeker, K., Crane, T. A., Sanogo, O. M., \& Giller, K. E. (2016). Waking the sleeping giant: Agricultural intensification, extensification or stagnation in Mali's Guinea Savannah. Agricultural Systems, 148(2016), 58-70.

Peterson, A. M., Helgason, W. D., \& Ireson, A. M. (2016). Estimating field-scale root zone soil moisture using the cosmic-ray neutron probe. Hydrology and Earth System Sciences, 20, 1373-1385.

Rahman, H. (2006). Number and weight of cotton lint fibres: Variation due to high temperatures in the field. Australian Journal of Agricultural Research, 57, 583-590.

Rockström, J., \& Barron, J. (2007). Water productivity in rainfed systems: Overview of challenges and analysis of opportunities in water scarcity prone savannahs. Irrigation Science, 25, 299-311.

Rockström, J., Karlberg, L., Wani, S. P., Barron, J., Hatibu, N., Oweis, T., et al. (2010). Managing water in rainfed agriculture: The need for a paradigm shift. Agricultural Water Management, 97(4), 543-550.

Sun, S., Sun, G., Cohen, E., McNulty, S. G., Caldwell, P. V., Duan, K., et al. (2016). Projecting water yield and ecosystem productivity across the United States by linking an ecohydrological model to WRF dynamically downscaled climate data. Hydrology and Earth System Sciences, 20, 935-952.

Swallow, B., Garrity, D., \& Noordwijk, M. V. (2001). The effects of scales, flows, and filters on property rights and collective action in catchment management. CAPRi working paper, Washington, DC, IFPRI, Open File Report 18.

Traoré, B., Corbeels, M., van Wijk, M. T., Rufino, M. C., \& Giller, K. E. (2013). Effects of climate variability and climate change on crop production in southern Mali. European Journal of Agronomy, 49, $115-125$.

Traoré, K. B., Gigou, J. S., Coulibaly, H., \& Doumbia, M. D. (2004). Contoured ridge-tillage increases cereal yields and carbon Sequestration. In 13th International soil conservation organisation conference, Brisbane, July 2004. Conserving Soil and Water for Society: Sharing Solutions, 126 (p. 10).

Traoré, K., Sidibe, D. K., Coulibaly, H., \& Bayala, J. (2017). Optimizing yield of improved varieties of millet and sorghum under highly variable rainfall conditions using contour ridges in Cinzana, Mali. Agriculture \& Food Security. https://doi.org/10.1186/s40066-016-0086-0.

Traoré, B., van Wijk, M. T., Descheemaeker, K., Corbeels, M., Rufino, M. C., \& Giller, K. E. (2014). Evaluation of climate adaptation options for Sudano-Sahelian cropping systems. Field Crops Research, 156, 63-75.

Tucker, C. J., Grant, D. M., \& Dykstra, J. D. (2004). NASA's global orthorectified Landsat data set. Photogrammetric Engineering \& Remote Sensing, 70(3), 313-322. 
Van der Pol, F. (1991). L'épuisement des terres, une source de revenus pour les paysans au Mali Sud. In Savanes d'Afriques, terres fertiles? (pp. 403-418). Paris: Ministère de la Coopération.

Walker, D., Forsythe, N., Parkin, G., \& Gowing, J. (2016). Filling the observational void: Scientific value and quantitative validation of hydrometeorological data from a community-based monitoring programme. Journal of Hydrology, 538, 713-725.

Wani, S. P., Anantha, K. H., Sreedevi, T. K., Sudi, R., Singh, S. N., \& D’Souza, M. (2011). Assessing the environmental benefits of watershed development: Evidence from the Indian semi-arid tropics'. Journal of Sustainable Watershed Science \& Management, 1(1), 10-20.

Wani, S. P., Joshi, P. K., Raju, K. V., Sreedevi, T. K., Wilson, M. J., Shah, A., Diwakar, P. G., Palanisami, S., Marimuthu, A. K., Ramakrishna, Y. S., Sundaram, M. S. S., \& D’Souza, M. (2008). Community watershed as a growth engine for development of dryland areas. A comprehensive assessment of watershed programs in India, Andhra Pradesh, India. International Crops Research Institute for the Semi-Arid Tropics, Global Theme on Agro-ecosystems, Open File Report 47.

Zemadim, B. (2016). The challenges of rainfed agricultural practices in Mali-redefining research agendaA short communication. Advances in Plants \& Agriculture Research, 4(1), 00128. https://doi. org/10.15406/apar.2016.04.00128. http://medcraveonline.com/APAR/APAR-04-00128.php

Zemadim, B., McCartney, M., Langan, S., Sharma, B. (2013). A participatory approach for hydrometeorological monitoring in the Blue Nile River Basin of Ethiopia, Colombo, Sri Lanka: International Water Management Institute (IWMI). IWMI Research Report 155 (p. 32).

Zemadim, B., Tabo, R., Sogoba, B., Nicolas, F., \& Wani, S. P. (2014). Assessment of contour bunding technology for improved land and water management in Mali, Resilient Dryland Systems Research. International Crops Research Institute for the Semi-Arid Tropics (ICRISAT), Patancheru 502 324, Telangana, India, Open File Report 63 (p. 31). 